\title{
Social Capital: a Basis for Community Participation in Fostering Environmental Education and the Heritage Tourism Development of Cibalay Megalithic Site
}

\author{
Arzyana Sunkar, Resti Meilani, Tri Rahayuningsih and EK.S. Harini Muntasib
}

Department of Forest Resources Conservation and Ecotourism, Faculty of Forestry, Bogor Agricultural University

Corresponding author: arzyanas@gmail.com

\section{ARTICLE INFO}

Received

20 March 2016

Accepted

30 August 2016

Available online

15 September 2016

\section{ABSTRACT}

Social capital is an often-unrecognized staple of community participation in a tourism site's development, although social capital comprises elements essential for successful community-based participation. This paper discusses how the host community's participation in the tourism development of Cibalay Megalithic Site was driven by local social capital. Cibalay Megalithic Site is one of the last reminders of ancient beliefs and is an iconic landmark, located within the Bogor Regency of West Java, Indonesia. It is also within the protected area of Gunung Halimun Salak National Park. Cibalay Megalithic Site is a product of a socio-cultural environment, deriving from the relationship between man and nature. Thus, its tourism development should interpret this history and promulgate environmental education as one of the key elements of sustainable tourism. The local Village of Tapos I was established as a tourism village; within this village, the hamlet of Sinar Wangi was declared a conservation hamlet. Both designations were achieved due to local initiatives of the host community in developing local tourism, with Cibalay Megalithic Site as the iconic tourism focus of the area. The high level of trust towards local figures and visitors, the conservation norm of "leuweung hejo, masyarakat ngejo" (if the forest is green, then the people will be prosperous) underlying everyday local life that indicates the importance of nurturing nature, good inter-personal relations between village members, and good social networking with outsiders: all combined to create the conditions and motivation that facilitated collective action in developing local heritage tourism.

Keywords: social capital, community participation, environmental education, heritage tourism development, Cibalay Megalithic Site

\section{Introduction}

A great deal of tourism relies on places with natural, indigenous and historic significances which tourism products are based, that can be categorized as natural and cultural tourism of which are forms of heritage that must be preserved. Heritage sites are attractive tourism destinations all around the world, because it provides identity to the site (Sharpley and Telfer, 2002), especially related to culture, raising the importance of heritage tourism. Heritage tourism can be defined as visiting historical and archaeological sites for the purpose of acquiring knowledge or entertainment (Hasan and Jobaid, 2014), in which arts, culture and heritage form a key attraction for visitors, and a focus of their activities (Columbia, 2014). Cultural heritage resources will play a significant role in sustainable cultural, social, economic development of communities (sustainable tourism), so the physical fabric, that has influenced their creation, must be maintained 
(Chourasia and Chourasia in Ismail, Masron and Ahmad, 2014). In response to an increasing number of tourists demanding specialist tourism products. Pforr and Megerle (2006) and Ali-Knight (2011) heritage tourism can evolved as a potential niche tourism product and market that enhances visitors' awareness and appreciation on man civilization and human-built resources. These can be achieved through outdoor and recreational activities (Ali-Knight, 2011; Farsani, Coelho and Costa, 2011). A heritage tourist should learn and have appreciation on the heritage of the area he or she is visiting. Through environmental interpretation, which focuses on historical aspects, visitors' satisfaction will be enhanced and contributes to the conservation objectives of the product/site. Heritage tourism can share experiences with other modalities of tourism, yet remain distinct in its purpose and add new dimension to the tourism product offered.

Rich in its culture, Indonesia has been a popular holiday destination; not just in terms of etnicity but also human civilization. Preserving the historic remains of civilization for the enrichment and education of present and future generations is crucial to add wealth to our understanding of our own nation's heritage and specifically to our local cultural heritage. Enhancing cultural and heritage offering through sharing cultural stories and history with tourists and promoting historic places can create a richer, more memorable tourism experience (Columbia, 2014).

This is actually the great strength of the Cibalay Megalith Site, ('structures made of large stones, usually rough and unhewn, which conform to certain well marked types' (Perry, 1918: 10), i.e., providing a first-hand experience from original objects, in accordance with Tilden (1977) definition of interpretation, "An educational activity which aims to reveal meanings and relationships through the use of original objects, by firsthand experience, and by illustrative media, rather than simply to communicate factual information" (p. 11). First-hand experince is crucial to understanding of the objects as stated by (Hooper-Greenhill, 1994: 11), "The real experiences that we offer, of objects, of buildings, of sites and of people, are essential to learning". Experiences suggest that many visitors who visited a megalith sites are confronted with a megalith resource, forming an innate curiosity about man's historical culture and they would start to deliberate questions on human's history. In order to respect the cultural significance of the destination, local community needs to be directly involved in the planning and management of the site. Therefore cultural and heritage tourism development must encourage local participation; consequently, its planning and development must focus on the power of the people to withhold negative changes and alterations on their life and surroundings.

Reference Milic, Jovanovic and Krstic (2008) conclude that local community is the local driver in tourism activities, and an important factor for sustainable cultural tourism, as stated in (Cole, 2008: 58), 'support and pride in tourism development are especially important in the case of cultural tourism where the community is part of a product'. The authors based their conclusions on the observation that tourism services are mostly dependent on local institutions and participation of local communities. The emotional and cognitive bonds that individuals form with a place foster a sense of stewardship or desire to protect and care for that place (Halpenny, 2010). These are related with the expanding access to natural resources which are determined by the availability of local networks, collective actions, mutual trust, and social norms. These elements make up the working definition of social capital, in addition to cooperation, relationships, and social interaction (Pawar, 2006). This is in line with the results concluded by Thoyre (2008) and Liu et al. (2014), which confirm, that a high level of social capital encourage community's behaviour in environmental protection. All of these findings suggested the potential of social capital in enhancing community participation in cultural heritage tourism development.

The paper explored social capital elements that motivate the local communities to support heritage tourism development within their areas. It examines the existing elements of social capital that include relationship within the communities and how it relates to community empowerment and conservation education as getaway to sustainable tourism. 


\section{Methodology}

This study was designed as a research survey by analyzing social phenomena. The research is directed toward finding facts on the basis of factual phenomena of social capital that will be considered as supporting the development of tourism.

\section{A. Study Site}

The study was conducted in the Village of Tapos I within the Sub-district of Tenjolaya, District of Bogor in the Province of West Java. The object of the local heritage tourism is the Cibalay Megalithic Site (Figure 1).

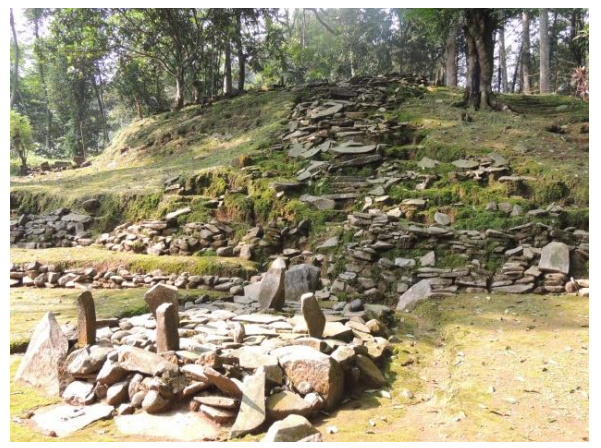

Figure 1 Cibalay Megalithic Site

Cibalay Megalithic Site is declared as a Cultural Heritage Site and is protected and regulated by Act No. 5/1992 on Cultural Heritage Sites. It is also located within the protected area of Gunung Halimun-Salak National Park. Thus formally, its status is legally protected by the Act and by its location, that is, within a protected area. The closest hamlet to the location is the Sinar Wangi Hamlet, which is given the status of a conservation hamlet.

The management of Cibalay Megalithic Site is organized by the Tourism Village Forum of Tapos 1 Village, which started in 2007 with the aim of promoting the tourism potential to improve the local welfare. Members of the forum were generally comprised of youths who are also members of Tapos 1Youth Village Tourism and also a member of the Activator Tourism Group consisting of members of various organizations such as the Regional Disaster Management Agency) and the National Community Empowerment Program. Both are

chaired by the same person, as well as the Tourism Village Forum. In addition to the Tourism Village Forum, there was also a group of officers guarding the site from the Cultural Heritage Preservation Office of Serang, totalling to 6 people (1 civil servant and 5 permanent employees).

\section{B. Data Collection Method and Analysis}

This research is descriptive in nature. Data collected coveredthe elements of social capital and general condition of the location (Table 1). The elements of social capital that were studied, were selected based on the scope of social capital at the micro (community) level as given by Grootaert and Bastelaer (2001), namely trust, local norms and value, local institutions (collective actions and coordination) and networks.

Table 1. Data and Infoemation

\begin{tabular}{|c|c|c|}
\hline \multirow[t]{2}{*}{ No. } & Data & \multirow[t]{2}{*}{ Souces of Data } \\
\hline & Elements of social capital & \\
\hline 1. & $\begin{array}{l}\text { Trust: within established } \\
\text { relationships and social } \\
\text { networks; trust extended to } \\
\text { strangers (often on the } \\
\text { basis of expectations of } \\
\text { behaviour or a sense of } \\
\text { shared norms); trust in the } \\
\text { institutions of governance } \\
\text { (including fairness of } \\
\text { rules, official procedures, } \\
\text { dispute resolution and } \\
\text { resource allocation) }\end{array}$ & $\begin{array}{l}\text { Head of sub-district, } \\
\text { village government, } \\
\text { local figures, religious } \\
\text { figure and members of } \\
\text { community (including } \\
\text { women, Qur'an recital } \\
\text { group, ) }\end{array}$ \\
\hline 2. & $\begin{array}{l}\text { Networks: density of } \\
\text { membership, diversity of } \\
\text { membership, extent of } \\
\text { connections to other } \\
\text { groups }\end{array}$ & $\begin{array}{l}\text { Head of sub-district, } \\
\text { village government, } \\
\text { local figures, religious } \\
\text { figure and members of } \\
\text { community (including } \\
\text { women, Qur'an recital } \\
\text { group, ) }\end{array}$ \\
\hline 3. & $\begin{array}{l}\text { Social norms and value; } \\
\text { implementation of norms, } \\
\text { politeness, obscenity, } \\
\text { religion, culture, and } \\
\text { government regulation }\end{array}$ & $\begin{array}{l}\text { Head of sub-district, } \\
\text { village government, } \\
\text { local figures, religious } \\
\text { figure and members of } \\
\text { community (including } \\
\text { women, Qur'an recital } \\
\text { group, ) }\end{array}$ \\
\hline 4. & $\begin{array}{l}\text { Collective action and } \\
\text { cooperation: participation } \\
\text { in social organization and } \\
\text { decision making, } \\
\text { frequency of attendance in } \\
\text { social organization, } \\
\text { motivation to assist others, } \\
\text { motivation to care and } \\
\text { preserve environment }\end{array}$ & $\begin{array}{l}\text { Head of sub-district, } \\
\text { village government, } \\
\text { local figures, religious } \\
\text { figure and members of } \\
\text { community (including } \\
\text { women, Qur'an recital } \\
\text { group, ) }\end{array}$ \\
\hline 5. & $\begin{array}{l}\text { General information of } \\
\text { Cibalay Megalithic Sites }\end{array}$ & $\begin{array}{l}\text { Village monographs, } \\
\text { documents and other } \\
\text { literatures, } \\
\text { observation }\end{array}$ \\
\hline
\end{tabular}


Triangulation method for socialrelated data and information was used, and consisted of interviews, observation and literature studies. Interviews were conducted on every weekend between August $18^{\text {th }}$ September $18^{\text {th }}, 2014$, with key informants and respondents from member of communities as shown in Table 1. The information gained from these interviews was supplemented by literature research in areas related to tourism, social capital, human behaviour and conservation education. Data and information collected were analyzed descriptively.

\section{Limitation of the study}

There are limitations to the study with regard to measuring social capital. This research did not use any quantitative measurement to determine the level of social capital condition within the village. Rather it used a qualitative approach, based on the analysis of other evidences on field.

\section{Results and Discussion}

\section{A. Elements of Social Capital for Tourism Development}

There are few opportunities and limited potentials for the local communities to invest and operate tourism businesses by themselves. Observations from Thailand Thammajinda (2013) and Indonesia reveal that benefit from tourism development have tended to by-pass local people in favour of outside investors, making them the main tourism actors who dominate tourism development in many local destinations. In the context of human development and the Cibalay Megalithic Site, social capital has a great influence because some dimensions of human development is strongly influenced by social capital such as the ability to solve problems together, raise collective consciousness to improve the quality of life and looking for opportunities to improve welfare. The existence of strong social ties will lead to an increase in welfare. This situation will increase the possibility of accelerating the development of individuals and groups within the community. The social capital elements of the communities within the study sites are tabulated below in Table 2
Table 2. Elements of social capital of the community in Tapos Village

\begin{tabular}{|c|c|c|c|}
\hline Trust & Social norms & $\begin{array}{l}\text { Collective } \\
\text { actions \& } \\
\text { cooperation }\end{array}$ & Networks \\
\hline $\begin{array}{l}\text { High trusts } \\
\text { towards } \\
\text { village } \\
\text { government } \\
\text {, fellow } \\
\text { communitie } \\
\text { s, local } \\
\text { figures, } \\
\text { outsiders \& } \\
\text { tourists; }\end{array}$ & $\begin{array}{l}\text { Social and } \\
\text { religious } \\
\text { norms are still } \\
\text { implemented; }\end{array}$ & $\begin{array}{l}\text { High } \\
\text { frequency of } \\
\text { attendance } \\
\text { on social } \\
\text { organization }\end{array}$ & $\begin{array}{l}\text { Existing } \\
\text { various social } \\
\text { organizations; } \\
\text { There is an } \\
\text { initiator in } \\
\text { establishing } \\
\text { networking; } \\
\text { Open to } \\
\text { tourism } \\
\text { development } \\
\text { collaboration; }\end{array}$ \\
\hline $\begin{array}{l}\text { Low - } \\
\text { medium } \\
\text { trust toward } \\
\text { people } \\
\text { involved in } \\
\text { Cibalay } \\
\text { archaeologi } \\
\text { cal site } \\
\text { managemen } \\
\text { t and } \\
\text { related } \\
\text { tourism }\end{array}$ & $\begin{array}{l}\text { Sanctions } \\
\text { given to those } \\
\text { breaking local } \\
\text { norms; } \\
\text { Social envy } \\
\text { toward people } \\
\text { involved in } \\
\text { Cibalay Site } \\
\text { management. }\end{array}$ & $\begin{array}{l}\text { High } \\
\text { participation } \\
\text { in decision } \\
\text { making }\end{array}$ & $\begin{array}{l}\text { Communities } \\
\text { still require } \\
\text { facilitator in } \\
\text { establishing } \\
\text { social } \\
\text { networks. }\end{array}$ \\
\hline
\end{tabular}

\section{1) Trust}

Among the people in Tapos 1Village, trust towards their government leaders, community leaders and religious leaders, were highly influenced by the roles of the new village head at the time, local figures and religious figures who actively participated in every village activities, such as Qur'an recitals in every hamlet, mutual cooperation work such as in repairing roads, keeping the environment clean, and attendance in every village meeting and village development planning colsultative meetings. These have encouraged the community members to actively participate in these activities as well.

Trusts in intra- and interpersonal social relations between individuals and between groups were also high and evident in everyday life. They can entrust a message for another member of community through other community member without being worried that the message would not be conveyed. On the contrary, the interpersonal economic relations related to income/livelihood, have prompted some dislike among the community. This was indicated by a little resentment shown towards the manager/caretakers of 
Cibalay Site. For example, some envyness could occur when the member (s) of the community received visitors for overnight stay at their home (homestays), despite the previous agreement on the criteria for the selection of houses. However, this did not cause any conflicts. Apart from the employment opportunity, this was caused by the different perceptions about the historical background of the Cibalay Site, between the officers and the local community. This fact has made the guarding officers to be more cautious to convey the story/myth/history of the site to the locals, so as not to create conflict, and tell the visitors who wanted to learn more about the history of the area to go directly to the head of the guarding officers. It is also influenced by the lack of knowledge and willingness of the staff to add their insights.

The gap was also influenced by the status of the officers who has no close relationship with the leadership of the village government, yet, they have a formal power status due to the support from the Cultural Heritage Preservation Office in Serang. Nevertheless one of the officers is also a member and also the head of one of the local community housing group (RW). This is one of the ways to maintain the merging of conflict. Therefore to increase trust and community participation of the heritage site, the local community must be involved in the planning and management of the Cibalay Site, including having a communal agreement of the historical background of the site. History is important to be told, especially since the area receives a great number of visitors during weekends and national holidays.

The local community was very much open to visitors, which show a high trust towards visitors. This was enhanced by the local Sundanese philosophy among the Tapos 1 Villagers in treating guests, i.e, "Someah hade kasemah," that can be translated into "polite, kind, and care towards visitors". The arrivals of visitors were also highly expected by the community, to obtain additional revenue.

The informal and subjective elements of interpersonal behaviour shaped people's minds and attitudes about interacting with others. When members within communities trust each other and the institutions that operated among

http://ojs.unud.ac.id/index.php/eot them, they should have easier access to reach agreements and conduct collective actions and cooperation resulting in networks. Trust improves cooperation by reducing expenses and improving the exchange of resources, skills and knowledge (Pretty and Ward, 2001). When trust in the social structure increases, it would enhance the individual's willingness to trust people who they were not familiar with. As a result, individuals are more likely to start and join a local organization that aims to improve the social, economic, or local environment (Pretty and Smith, 2004). It was evidenced from the research, that economic and social motivations formed the level of trust that the communities showed toward each other, their leaders and outsiders. The basic motivation of trust towards people, who were outsiders, was largely economic, such as the opportunity for employment and increasing local income.

\section{2) Social Norms}

The influence of local art and religious leaders in the villages has high effect on the implementation of social norms, while trust on the village governments determined the implementation of village government regulation. Social norms played important role in controlling and shaping the behaviour that grew in the community. Formal and informal rules, norms and sanctions are instrumental in putting the interests of group over individual interests in the formation of positive attitudes and behaviours towards environment.The influence of local art and religious leaders in the villages has high effect on the implementation of social norms, while trust on the village governments determined the implementation of village government regulation. According to Hasbullah, (2006), maintenance of group norms (adherence to the norms of religion, morality, and politeness) will strengthen the communities' social capital.

Customary norms are no longer hold true for Tapos 1Village community. Nowadays, people are following the government norms or regulations, including the rules of the village, and achieving agreement among members of community. One of the norms that is still strongly applied by the community embodied in the local motto 
of "leuweung hejo, masyarakat kudu ngejo", which can be translated into, "if we want to maintain the forest to keep providing to us, then we should be kind to the environment". This motto is engraved in the everyday life of the people in the Tapos 1 Village. This motto is also motivated by the designation of one of the hamlet, Sinar Wangi, as a conservation village.

Apart from customary norms, religious norms are very evident from the regular weekly Holy Qur'an recitals. The community also has a tendency to follow and implement what has been agreed and shared by the habit among fellow citizens, as well as the provisions of the religion or beliefs held. There was also a strong social control among members of te communities, in the form of sanctions for people who violated the existing norms, because it is their beliefs that member of community should not give bad name to the village.

\section{3) Collective actions and cooperation}

The level of desire to add and share experiences to other community members was apparent during the recital of Qur'an. In addition, the Tourism Forum also frequently held informal meetings called "ngariung" once a week at the campsite of Mount Salak on Saturday/Sunday, which opened in general, for every community member who wants to join. The meeting is used to discuss the development of te Tourism Village Forum as wel as the development of tourism in Tapos i Village in general.

Frequency of participation of community, in social organizations is generally high, especially among the youths. Among adults, the participation is generally moderate and normative. This was observed to affects the participation in decision-making on social organization, in which youths were more active in participation and decisionmaking. Various collective action based on mutual trust would increase the participation in a variety of shapes and dimensions, especially in the context of building a common progress. The purposes of collective action within the study site consisted on primarily community-organized activities for religious purposes and providing environmental services. Trust fostered the collective actions and cooperation within the studied village. This was in line with the high level of trust toward the village government, which validated the importance of local leadership (the village government) in empowering community.

There is also a form of citizen awareness in the surrounding forest environment, especially residents of Sinar Wangi Hamlet. Community participation in maintaining forest environment makes Kampung Sinar Wangi established as one of the pilot conservation village of the Gunung Halimun Salak National Park. Therefore, residents of Kampung Sinar Wangi have a strong motivation to foster stewardship among fellow community and the environment in terms of protecting the environment in the surrounding forests and villages.

\section{4) Networks}

Strong social capital would depend on the capacity of community groups to build its network. The research confirmed that trust provided the foundation for norms and collective actions which all together determined the level of networking. Table 3 confirmed that the higher the level of trust that the communities have towards their fellow communities, local figures, leaders and outsiders, the higher were the ability to established networks and build local organizations/associations. The high trust towards outsiders proved to enhance the openness of the communities to develop networks. Another important result was that the higher the need to improve economic condition, the higher the participation in tourism.

Various social networks are observed in Tapos 1 Village. This is apparent since every social network has a foundation in the form of institutional organizations/forums/groups, whose membership is formal and open to the public. Willingness to establish cooperation network among the community members were shown by the presence of member of community figure who pioneered the establishment of networks, which will be followed by the community participation. This can be 
achieved only with high level of trust to the local figure. The local community are also very receptive or cooperate well to establish social networks in developing tourism within the village. This was evident from some of the networks that have been developed until now, which include Department of Tourism and Culture of the District of Bogor, West Java Tourism Village Forum and the Regional Disaster Management Agency. The underlying motivation for this, was to enhance welfare of the village through tourism development and other village activities.

As the phenomenon of 'bottom-up', social capital is created when individuals developed network connections. In other words, strong social capital would depend on the capacity of community groups to build its network. The research confirmed that trust provided the foundation for norms and collective actions which all together determined the level of networking. Table 3 confirmed that the higher the level of trust that the communities have towards their fellow communities, local figures, leaders and outsiders, the higher were the ability to established networks and build local organizations/associations. The high trust towards outsiders proved to enhance the openness of the communities to develop networks. Another important result was that the higher the need to improve economic condition, the higher the participation in tourism.

Heritage tourism development of Cibalay Megalithis Site has been providing benefits to the local village such employments, homestays owners, parking spaces and parking money, trades, etc. The road leading to this village has also been improved and various tourism objects have emerged due to the arrivals of visitors who wanter to visit the heritage site. This eventually add revenues to the local government and more visitors are expected to arrive/visit the Cibalay Megalithic Site, especially with the assistance from media that brought up the importance of megalithic sites as a $\mathrm{n}$ education media to learn abour our civilization heritage.

\section{B. Social capital as a basis for community participation in fostering environmental education}

The sustainability of Cibalay megalithic site is greatly influenced by the community and the visitors who come to the Site. They have to demonstrate proenvironmental behavior in order for the site to sustain. Pro-environmental behavior can be cultivated in both residents and visitors by means of environmental education; a management tool, a mean to strengthen people's environmental concern which would lead to environmentally responsible behaviour or pro-environment behaviour (Stapp, 1969; Hungerford and Volk, 1990).

Active local environmental groups can provide the source to generate social capital in the community (Klyza, Savage and Isham, 2004). Such group existed in Tapos 1 Village, i.e. the Tourism Village Forum. The Forum had strong influence to the community, particularly in tourism management of the village. Using the influence, the Forum could encourage community participation in environmental education, in which the importance of human history and the value of Mount Salak and Cibalay megalithic site as tourism destination were emphasized. Values can motivate people to engage in certain behavior (Kollmuss and Agyeman, 2002). Conveying the values of Mount Salak and the site is expected to increase people's appreciation toward the resources, enhance their affinity with the resources, and in turn urge them to protect the resource. Values are related to norms. Changing the way people value things, is expected to also change the norms which regulates their action. Changing social norms can ensure the long-term protection of the environment (Pretty and Smith, 2004). Norms, rules, and values are the means to achieve long-term sustainability (Liu et al., 2014). In addition, people's participation can be promoted by Environmental education (EE) for the residents can take the path of formal and nonformal educations, while for the visitors it would be best given in interpretation/interpretive programs. Formal EE means providing the issues of $\mathrm{EE}$ in the curriculum, either by integrating the issues in 
to the existing subjects, or designing new subject. Non formal EE can make use of the activities already exists in the community, such as Islamic study, informal discussion, or training and courses by design. A welldesigned and well-implemented interpretation can increased visitors knowledge of the host area, positive attitude toward the resources, general environmental behavioral intentions, and support of conservation (Powell and Ham, 2008). Interpretive programs for the visitor can take advantage of the local guide and various exhibits install in the site to inform visitors on the history and the value of the site.

Community participation in sustainable tourism is also the key to the success of conservation efforts, because many tourism activities took place within protected areas (Sunkar, Rachmawati and Cereno, 2013). It is also supported by the statement of (Pretty and Smith, 2004) that many studies have shown the increased activity on the conservation of natural resources in and around the communities of protected area, which showed a good relationship between the members of the community, between and within groups, and networks.

Social networks are indispensable for the success and sustainability of ecotourism development. According to Pretty and Smith (2004), strong positive relationships within and between social groups, could significantly lower the cost of tourism operations through cooperation, facilitation, collaboration, investment in collective action, reduction of the likelihood of an individual engaging in activities that generate negative impact on the group, and increase the chances of innovation.

This research have found that trust especially in village government was the most crucial element of social capital that formed the foundation for a successful cultural heritage development because it led to networks that would empower the communities. This result was similar to that of Oktadiyani (2010) who found that trust and norms were the major elements of social capital in the communities of Kutai National Park buffer zone in, while research by Baksh et al. (2013) found that norms was strongly influenced that the development of ecotourism in the region was strongly influenced by the

http://ojs.unud.ac.id/index.php/eot networks followed by public participation although it was not influenced by the beliefs and norms, whereas.

\section{Conclusion}

In the context of human development and the Cibalay Megalithic Site, social capital has a great influence because some dimensions of human development that were evident in Tapos 1 Village were strongly influenced by social capital such as the ability to solve problems together, raise collective consciousness to improve the quality of life, and looking for opportunities to improve welfare. The existence of strong social ties will lead to an increase in welfare. This situation will increase the possibility of accelerating the development of individuals and groups within the community.

Local village leadership had significant effects on maintaining a solid rural community. The higher the social capital, the stronger is the ability of the community to resist changes on themselves and on their environment. When enhanced with conservation education, it would improve the conduct of sustainable tourism by empowering the community's capacity to work together to address their common needs, fostering greater inclusion and cohesion, and increasing transparency and accountability. This research have found that trust especially in village governmet was the most crucial element of social capital that formed the foundation for a successful cultural heritage development because it led to networks that would empower the communities. In addition, this research also found that participation of the local community is crucial in the planning and management of Cibalay Megalith Site to provide the visitors with environment education and information on the histrocal background of the area.

\section{Acknowledgement}

Thanks are due to the Indonesian Ministry of Education and Culture and Bogor Agricultural University who made this research possible by awarding this research with funding through national competitive grants (DIPA IPB No. SPK. 21/IT3.11/LT/2014 dated June 2 $2^{\text {nd }}, 2014$. 


\section{References}

Ali-Knight, J. M. (2011) The role of niche tourism products in destination development. Zahed University.

Baksh, R., Soemarno, T., Hakim, L. and Nugroho, I. (2013) 'Social capital in the development of ecotourism: A case study in Tambaksari Village Pasuruan Regency, East Java Province, Indonesia', J Basic Appl Sci Res, 3(3), pp. 1-7.

Cole, S. (2008) Tourism, culture and development: Hopes, dreams and realities in East Indonesia. Channel View Publications.

Columbia, D. B. (2014) Cultural and Heritage Tourism Development Guide.

Farsani, N. T., Coelho, C. and Costa, C. (2011) Geoparks and geotourism: new approaches to sustainability for the 21st century. Universal-Publishers.

Grootaert, C. and Bastelaer, T. V (2001) 'Understanding and Measuring Social Capital: Social Capital Initiative Working Paper. 24', World Bank.

Halpenny, E. A. (2010) 'Pro-environmental behaviours and park visitors: The effect of place attachment', Journal of Environmental Psychology. Elsevier, 30(4), pp. 409-421.

Hasan, M. and Jobaid, M. I. (2014) 'Heritage tourism marketing: status, prospects and barriers', IOSR Journal of Business and Management (IOSRJBM), 16(5), pp. 40-48.

Hasbullah, J. (2006) Social Capital: menuju keunggulan budaya manusia Indonesia. MR-United Press.

Hooper-Greenhill, E. (1994) 'Museum Communication: An Introductory Essay', in Educational Role of the Museum, Hooper-Greenhill, Ed. London: Routledge.

Pawar, M. (2006) 'Social capital ?', The Social Science Journal, 43, pp. 211-226.

Perry, W. J. (1918) The megalithic culture of Indonesia. University Press.

Milic, J. V, Jovanovic, S. and Krstic, B. (2008) 'Sustainability performance management system of tourism enterprises', FACTA UNIVERSITATIS. Series: Economics and Organization, 5(2), pp. 123-131.

Oktadiyani, P. (2010) Capital social of people living in the buffer zone of Kutai National Park in developing ecotourism (Modal sosial masyarakat kawasan penyangga Taman Nasional Kutai (TNK) dalam pengembangan ekowisata). Institut Pertanian Bogor.

e-ISSN: 2407-392X. p-ISSN: 2541-0857 
Pforr, C. and Megerle, A. (2006) 'Geotourism: a perspective from southwest Germany', Geotourism. Routledge, pp. 118-139.

Powell, R. B. and Ham, S. H. (2008) 'Can ecotourism interpretation really lead to pro-conservation knowledge, attitudes and behaviour? Evidence from the Galapagos Islands', Journal of sustainable tourism. Taylor \& Francis, 16(4), pp. 467-489.

Pretty, J. and Smith, D. (2004) 'Social capital in biodiversity conservation and management', Conservation biology. Wiley Online Library, 18(3), pp. 631638.

Pretty, J. and Ward, H. (2001) 'Social capital and the environment', World development. Elsevier, 29(2), pp. 209227.

Sharpley, R. and Telfer, D. J. (2002) Tourism: a vehicle for development? Channel View Publications.

Stapp, W. B. (1969) 'The concept of environmental education', Environmental Education. Taylor \& Francis, 1(1), pp. 30-31.

Sunkar, A., Rachmawati, E. and Cereno, R. (2013) 'Ecotourism development in Brunei Darussalam, Indonesia, Lao PDR, Myanmar, Singapore and Philippines', in Opportunities and challenges of ecotourism in ASEAN countries, S. Kim, M. Kang, and D. Sukmajaya, Eds. Seoul: Jungmin Publishing Co, pp. 54-89.

Thammajinda, R. (2013) 'Community participation and social capital in tourism planning and management in a Thai context'. Lincoln University.

Thoyre, A. (2008) Community effects on individual pro-environmental action: social capital and environmental sustainability in the United States. Lunds Universitet.
Tilden, F. (1977) 'Interpreting our heritage'. Chapel Hill: University of North Carolina Press. 